\title{
Takayasu Arteritis with Systemic Lupus Erythematosus: A Rare Association
}

\author{
Soukaina Oumli1 ${ }^{1}$, Jaouad Yousfi ${ }^{1 *}$, Laila Benjilali ${ }^{1}$, Lamiaa Essaadouni ${ }^{1}$
}

${ }^{1}$ Department of Internal Medicine, University Hospital of Mohammed VI, Marrakesh, Morocco

DOI: $10.36347 /$ sjmcr.2021.v09i04.015

| Received: 12.03.2021 | Accepted: 19.04.2021 | Published: 22.04.2021

*Corresponding author: Jaouad Yousfi

\section{Abstract}

Takayasu arteritis (TA) is a systemic vasculitis typically occurring in young female patients, and still of unknown etiology. This vasculitis rarely coexists with systemic lupus erythematosus (SLE). We report the observation of a 45year-old patient diagnosed with TAwho presented with upper extremity ischemia and wall thickening with a good response to the association of methotrexateand corticosteroids. Five years later, she presented with bilateral inflammatory arthralgia of the middle joints with malar rash. Biological assessment showed lymphopenia, positive anti-nuclear antibodies at 1/1280 with a homogeneous florescence, positive anti-dsDNA and proteinuria at $4.3 \mathrm{~g} / \mathrm{day}$. The diagnosis of SLEassociated with TA was established.

Keywords: Lupus- Takayasu arteritis -Corticosteroids.

Copyright $\odot 2021$ The Author(s): This is an open-access article distributed under the terms of the Creative Commons Attribution 4.0 International License (CC BY-NC 4.0) which permits unrestricted use, distribution, and reproduction in any medium for non-commercial use provided the original author and source are credited.

\section{INTRODUCTION}

The frequency of the association of systemic lupus erythematosus (SLE) and Takayasu arteritis (TA) is unknown and probably underestimated. TA is anidiopathic, systemic inflammatory disease, typically involving the aorta and its main branches. While SLE affects mainly the small vessels. The coexistence of these two diseases has been rarely reported. Here we report a case where SLE was preceded by TA.

\section{CASE Report}

A 45 year-old woman was diagnosed for 16 years withTA revealed byan intermittent claudication of upper limbs, without ocular or cutaneous features. Clinical examination showed anasymmetric blood pressure in upper limbs (Systolic blood pressurewas at $150 \mathrm{mmHg}$ on the right and $110 \mathrm{mmHg}$ on the left), a reduction of radial and humeral pulses, without vascular bruits.

Doppler ultrasound of the upper limb showed an inflammatory arterial wall thickening ofsubclavian arteries with a low velocity biphasic flow of the axillary and humeral right arteries. Computed tomography angiogramshowed partial stenosis of the right humeral artery and infrarenal abdominal aorta. The patient was treated with corticosteroids ( $1 \mathrm{mg} / \mathrm{kg} /$ day $)$, methotrexate
(20 mg/week) and platelet antiaggregant, with agood clinical evolution.

Five years later, the patient presented with inflammatory polyarthralgia involving the middle joints with pitting edema of the lower limbs.

Biological findings showed lymphopenia and abiological inflammatory syndrome (accelerated erythrocyte sedimentation rate of $99 \mathrm{~mm}$; a CRP of 20 $\mathrm{mg} / \mathrm{l}$ and anemia of inflammation with haemoglobin of $10.7 \mathrm{~g} / \mathrm{dl})$. Anti-nuclear and anti-dsDNA antibodies were positive.

Proteinuria was positive at $4.3 \mathrm{~g} /$ day and the renal function was normal. Renal biopsy revealedextramembranous glomerulonephritis. The diagnosis of SLE associated with TA was established. The patient was treated withcorticosteroids and cyclophosphamide for lupus nephritis with a good evolution.

\section{DiSCUSSION}

Takayasu arteritis is a granulomatous vasculitis of the aorta and its branches. Itis predominantly a disease of young adults in the second and third decades of life, most commonly seen in Japan andsouth East Asia [1]. 
As with SLE, there is a marked female predominance of TA.Itcan be associated with systemic or granulomatous diseasessuch asulcerative colitis, Crohn's disease, ankylosing spondylitis, and more rarely SLE and sarcoidosis. These associations are exceptional but seem to be non-fortuitous. The simultaneous development of SLE and TA is rare with only twenty observations reported in the literature. According to some authors, the association between SLE and TA remains unclearsince aortitis are sometimes observed during SLE [2-4].

Vascular disease is frequent in patients with SLE (15\% of patients), and is associated with high morbidity and mortality. This may be explained by the presence of anti-phospholipid antibodies, diffuse vasculitis or secondary atherosclerosis. It generally involves small vessels, thus aortic damage, aneurysms, occlusions and dissections are very exceptional [5].

On the other hand, vascular damage in TA is due to mononuclear cells and granulomatous infiltration associated with parietal fibrosis leading to aortic obstruction [6].

The diagnosis of SLE is certain in our patient. TA diagnosis was made according to the American College of Rheumatology criteria including (1) age < 40 years; (2) intermittent claudication of the upper limbs; (3) decreased left brachial artery pulse; (4) blood pressure difference $>10 \mathrm{~mm} \mathrm{Hg}$; and (5) arteriogram abnormality [7].

In our case, the coexistence of both vascular and renal damage was a therapeutic dilemma. However, after the remission of thearteritis,cylophosphamidewas started for the proliferative nephritis. The follow-up showed an improvement of all systemic manifestations.

\section{CONCLUSION}

The association of SLE and TA is very rare. Since $\mathrm{T}$ cell-mediated immunity plays a major role in both the diseases it may be an overlap of the immune mechanism which leads to the coexistence of both diseases. The absence of specific SLE markers in patients with TA who subsequently develop SLE suggests that the coexistence of these conditions may be coincidental.

\section{REFERENCE}

1. Lambert M, Hachulla E, Huglo D, Hatron PY. Maladie de Takayasu: caractéristiques cliniques, prise en charge diagnostique, traitement et pronostic. MédecineNucléaire. 2009; 33: 512-517.

2. Sokalski DG, Copsey Spring TR. Large artery inflammation in systemic lupus erythematosus. Lupus. 2013;22(9):953.

3. Saxe P, Altman R. Takayasu's arteritis syndrome associated with systemic lupus erythematosus. Sem Arthritis Rheum. 1992; 21(5):295-305.

4. Igarashi $\mathrm{T}$, Nagaoka S, Matsunaga K, Katoh K, Ishigatsubo Y, Tani K, Okubo T, Lie JT. Aortitis syndrome (Takayasu's arteritis) associated with systemic lupus erythematosus. J Rheumatol, 16:1579-1584.

5. Pyrpasopoulou, A, Chatzimichailidou S, Aslanidis S. "Vascular disease in systemic lupus erythematosus," Autoimmune Diseases, 2012; 1(1).

6. Arnaud L, Haroche J, Piette JC, Amoura Z. Takayasu arteritis: a French single centre experience. Rev Med Interne. 2010 Mar;31(3):208- 15

7. Arend WP, Michel BA, Bloch DA, Hunder GG, Calabrese LH, Edworthy SM, Fauci AS, Leavitt RY, Lie JT, Lightfoot Jr RW, Masi AT. The American College of Rheumatology 1990 criteria for the classification of Takayasu arteritis. Arthritis \& Rheumatism. 1990 Aug;33(8):112934. 